\title{
Do Analysts Understand Conservatism?
}

\author{
Bo Ouyang ${ }^{1} \&$ Huishan Wan $^{2}$ \\ ${ }^{1}$ Management Division, Pennsylvania State University-Great Valley, Malvern, PA 19355, USA \\ ${ }^{2}$ School of Accountancy, University of Nebraska-Lincoln, Lincoln, NE 68588, USA \\ Correspondence: Huishan Wan, School of Accountancy, University of Nebraska-Lincoln, Lincoln, NE 68588-0488, \\ USA. Tel: 1-402-472-6055. E-mail: hwan2@unl.edu
}

Received: October 24, 2013

Accepted: December 2, 2013

Online Published: December 3, 2013

doi:10.5430/afr.v3n1p1

URL: http://dx.doi.org/10.5430/afr.v3n1p1

\begin{abstract}
This study investigates whether analysts understand accounting conservatism. It is well documented that financial reporting system exhibits conservatism, that is, bad news is recognized in earnings in a timelier manner than good news. We argue if analysts understand accounting conservatism, the forecasts should exhibit similar conservatism as earnings, or bad news is incorporated into analysts' forecasts in a timelier fashion than good news. We find that analysts' short-term earnings forecasts exhibit similar conservatism as accounting earnings. We further find that as the forecast horizon increases the conservatism becomes weaker. On the contrary, the analysts' long-term forecasts are not conservative. Collectively, the results suggest analysts do understand accounting conservatism.
\end{abstract}

Keywords: Conditional conservatism, Differential timeliness, Analysts' long-term forecasts

\section{Introduction}

This paper investigates whether analysts understand conservatism. Earnings information plays a prominent role in firm valuation, firm contracting, and investors' investment decision. This importance creates the demand for earnings forecasts. To meet this demand, financial analysts generate quarterly, annual and multi-year earnings forecasts. It is well documented that financial reporting system exhibits conservatism, that is, bad news is recognized in earnings in a timelier manner than good news (Basu 1997). Further, conservatism draws a lot of attention of regulators, practitioners, and accounting researchers (Watts 2003). However, relatively little is known about whether and how financial analysts, as important intermediaries in the capital market, understand and incorporate conservatism when they generate earnings forecasts.

Pae and Thornton (2010) examines whether analyst earnings forecasts allow for accounting conservatism. They hypothesize that if analysts correctly allowed for conservatism, differences in earnings conservatism would be unassociated with analysts' forecast error. They find that average year end forecast error differs between firms with higher accounting conservatism and those with lower accounting conservatism. Thus, they conclude that analysts' earnings forecasts do not fully incorporate the implications of earnings conservatism. Louis, Lys, and Sun (2008) also investigate the conservatism and analyst earnings forecast bias. They hypothesize and find supporting evidence that analysts do not fully adjust their initial forecasts for conservatism.

Both Pae and Thornton (2010) and Louis, Lys, and Sun (2008) examine analysts' forecast errors to explore the question whether analysts incorporate accounting conservatism in their forecasts. However, we argue analysts' forecast errors are not the best place to look for the answer of the question as prior studies suggest that analysts' forecast errors/bias are very noisy (Matsumoto 2002; Bartov et al. 2002). For example, Brown and Caylor (2005) indicate that management has the pressure and incentives to meet or beat analysts' forecasts and they manage the analysts' forecast down to a beatable level. Thus, the findings from examining analysts forecast errors cannot be attributed solely to whether analysts understand conservatism.

Instead of focusing on analyzing forecast errors, we examine analysts' forecasts per se in order to understand whether analysts incorporate conservatism into their forecasts. Prior studies find that forecast accuracy is very important for analysts' reputation and compensation (Hong and Kublick 2003, Mikhail, Walther, and Willis 1999). Therefore, if analysts understand conservatism, when they generate forecasts for next year's earnings, we expect the forecasts exhibit similar conservatism as earnings, that is, bad news is incorporated into analysts' forecasts in a more timely fashion than good news. Furthermore, the good news and bad news refer to gains and losses that will be realized in 
the future. If analysts understand the conservatism, when they generate long-term forecasts, they would incorporate the good news into their forecasts. That is, analysts' long-term forecasts will not show conservatism. Therefore, in order to answer the question whether analysts understand the conservatism, we need to analyze not only the short-term forecasts but also the long-term forecasts.

Our findings are consistent with our prediction. We find that analysts' short-term earnings forecasts incorporate bad news in a timelier manner than good news. However, for the long-term forecasts, there is no evidence for differential timeliness of bad news versus good news. Together the evidence suggests that analysts understand conservatism and incorporate it into their forecasts.

This paper contributes to the accounting conservatism and analysts forecasts literature. First, this paper enhances our understanding how analysts incorporate conservatism into their forecasts. We depart from prior literature as we use a different proxy less vulnerable to noise and bias to examine this important research question; Second, the findings of this paper propose a good candidate for the proxy of good/bad news. In the accounting conservatism literature, it is important to find a good proxy for good news and bad news. Following Basu (1997), many studies use unexpected stock return as the proxy for good news and bad news. However, as recent literature highlights, there are economic and econometric limits of Basu's model and measure of conservatism (Dietrich et al. 2007; Givoly et al. 2007; Roychowdhury and Watts 2007). Gotti (2008) introduces a new proxy for good/bad news about future earnings: the number of changes in financial analysts' EPS forecasts. One concern about this proxy is if the short-term analysts' forecasts are conservative, then it is hard to believe the number of changes in short-term analysts' forecasts is a good proxy for good/bad news. This study's findings suggest that analysts' long-term forecasts may be a better candidate for the proxy of good/bad news.

\section{Research Design}

\subsection{Hypothesis Development}

It is well documented that financial accounting is conservative in that it requires greater verifiability for the accounting recognition of gains (good news) versus losses (bad news) (Basu 1997, LaFond and Watts 2008). Using firms' stock negative and positive stock returns as proxies for bad news and good news respectively, Basu (1997) finds the contemporaneous sensitivity of earnings to negative returns is two to six times that of earnings to positive returns. After Basu's (1997) influential work, there are many studies on conservatism. One stream of the research is analysts' forecasts and conservatism.

Financial analysts are important intermediaries in the capital market and they supply substantial amount of information flowing to the market. Prior studies find that forecast accuracy is very important for analysts' reputation and compensation (Hong and Kubick 2003, Mikhail, Walther, and Willis 1999). Hong and Kubick (2003) find that relatively accurate forecasters are more likely to experience favorable career outcomes, such as moving up to a high-status brokerage house. If analysts strive to generate accurate forecasts for future earnings, and earnings exhibits asymmetrical timeliness on loss versus gain recognition, it is a natural question to ask whether the analysts' short-term earnings forecasts exhibit the similar conservatism pattern as earnings.

Pae and Thornton (2010) examine whether analysts' earnings forecasts fully impound the implications of accounting conservatism. They hypothesize that if analysts correctly allowed for conservatism, differences in earnings conservatism would be unassociated with analysts' forecast error. They find that average year end forecast error differs between firms with different levels of accounting conservatism. Thus, they conclude that analysts' earnings forecasts do not fully incorporate the implications of earnings conservatism. Louis, Lys, and Sun (2008) also investigate the conservatism and analyst earnings forecast bias. They hypothesize and find supporting evidence that analysts do not fully adjust their initial forecasts for conservatism.

Both papers examine analysts' forecast errors to address the question. However, we argue analysts' forecast errors are not the best place to look for the answer of the question whether analysts understand conservatism as prior studies suggest that analysts' forecast errors/bias are very noisy (Matsumoto 2002; Bartov et al. 2002). For example, Brown and Caylor (2005) indicate that management has the pressure and incentives to meet or beat analysts' forecasts and they manage the analysts' forecasts down to a beatable level. Thus, the findings from examining analysts forecast errors cannot be attributed solely to whether analysts understand conservatism.

Instead of focusing on analyzing forecast errors, we examine analysts forecasts themselves in order to understand whether analysts incorporate conservatism into their forecasts. If analysts understand conservatism and they want to generate accurate forecasts, when they generate forecasts for next year's earnings, we expect the forecasts exhibit 
similar conservatism as earnings, that is, bad news is incorporated into analysts' forecasts in a more timely fashion than good news. Thus, the first hypothesis, concerning the analysts' short-term forecasts is as follows.

Hypothesis 1: If the analysts understand conservatism and incorporate it into their earnings forecasts, their short-term earnings forecasts will have the similar conservatism as the earnings.

Furthermore, the good news and bad news refer to gains and losses that will be realized in the future. Conservatism implies the delayed recognition of good news in the current earnings. However, in a long run, the good news will be eventually recognized into earnings when it is realized. If analysts understand the conservatism, when they generate long-term forecasts, they would incorporate both the bad news and the good news into their forecasts. That is, analysts' long-term forecasts will not show conservatism. Hence, the second hypothesis regarding the analysts' long-term forecasts is as follows.

Hypothesis 2: If the analysts understand conservatism and incorporate it into their earnings forecasts, their long-term earnings forecasts are not conservative.

\subsection{Regression Models}

Basu (1997)'s conservatism measure is widely used. (Note 1) He measures conservatism as the extent to which "bad news" (proxied by firms' negative stock returns) are reflected in earnings more quickly than "good news" (proxied by firms' positive stock returns). Following Basu (1997) and Givoly et al (2007), we measure conservatism as follows:

$$
\mathrm{EPS}_{\mathrm{it}} / \mathrm{P}_{\mathrm{it}-1}=\alpha_{0}+\alpha_{1} \mathrm{NEG}_{\mathrm{it}}+\alpha_{2} \mathrm{RET}_{\mathrm{it}}+\alpha_{3} \mathrm{RET}_{\mathrm{it}}{ }^{*} \mathrm{NET}_{\mathrm{it}}+\varepsilon_{\mathrm{it}}
$$

Where $\mathrm{EPS}_{\mathrm{it}}$ is the earnings per share for firm $\mathrm{i}$ in fiscal year $\mathrm{t}, \mathrm{P}_{\mathrm{it}-\mathrm{i}}$ is stock price per share at the beginning of fiscal year $t, \mathrm{RET}_{\mathrm{it}}$ is the stock return on firm i from 9 months before fiscal year end $\mathrm{t}$ to three months after fiscal year end $\mathrm{t}$, $\mathrm{NEG}_{\text {it }}$ is a dummy variable $=1$ if $\mathrm{RET}_{\text {it }}<0,=0$ otherwise. Coefficient $\alpha_{2}$ is the slope coefficient for positive $\mathrm{RET}_{\mathrm{it}}$ while the slope coefficient for negative $\mathrm{RET}_{\text {it }}$ is $\alpha_{2}+\alpha_{3} . \alpha_{3}$ is the differential slope for bad news versus good news. If $\alpha_{3}$ is positive, that indicates net income reflects "bad news" more quickly than "good news", and consequently, earnings are conservative. We also examine a derivative measure obtained from Regression (1), calculated as $\left(\alpha_{2}+\right.$ $\left.\alpha_{3}\right) / \alpha_{3}$. This ratio, which we refer to as the "differential timeliness" ratio, was introduced by Pope and Walker (1999). It reflects the relative timeliness of the firm's incorporation of bad news relative to good news in earnings.

To test Hypothesis 1, we estimate the following regression:

$$
\mathrm{AF}_{\mathrm{it}} / \mathrm{P}_{\mathrm{it}-1}=\beta_{0}+\beta_{1} \mathrm{NEG}_{\mathrm{it}}+\beta_{2} \mathrm{RET}_{\mathrm{it}}+\beta_{3} \mathrm{RET}_{\mathrm{it}} * \mathrm{NET}_{\mathrm{it}}+\varepsilon_{\mathrm{it}}
$$

where $\mathrm{AF}_{\mathrm{it}}$ is the consensus analysts' short-term forecasts of earnings per share for firm $\mathrm{i}$ in year t. $\beta_{2}$ measures the timeliness of analysts' short-term forecasts with respect to good news (positive return), and $\beta_{3}$ measures the incremental timeliness of analysts' short-term forecasts with respect to bad news (negative return). If analysts' short-term forecasts are conservative, then $\beta_{3}$ will be positive.

To test Hypothesis 2, we estimate the following regression:

$$
\mathrm{AF}_{\mathrm{iLT}} / \mathrm{P}_{\mathrm{it}-1}=\gamma_{0}+\gamma_{1} \mathrm{NEG}_{\mathrm{it}}+\gamma_{2} \mathrm{RET}_{\mathrm{it}}+\gamma_{3} \mathrm{RET}_{\mathrm{it}} * \mathrm{NET}_{\mathrm{it}}+\varepsilon_{\mathrm{it}}
$$

where $\mathrm{AF}_{\mathrm{iLT}}$ is the consensus analysts' long-term forecasts of earnings per share for firm $\mathrm{i}$ in year t. $\gamma_{2}$ measures the timeliness of analysts' long-term forecasts with respect to good news (positive return), and $\gamma_{3}$ measures the incremental timeliness of analysts long-term forecasts with respect to bad news (negative return). If analysts' long-term forecasts incorporate both bad news and good news, then $\gamma_{3}$ will be insignificant.

\subsection{Sample Selection}

We collect the initial sample from 1985 to 2012 on Standard \& Poor's Compustat database (Primary-Supplementary-Tertiary, Full Coverage, and Research files) that have sufficient earnings per share. Our initial sample consists of 29,284 firms and 295,136 firm-years. Analysts' forecasts data are collected from IBES. We require firms have analysts' short-term (one to three years) and long-term forecasts. We delete 200,808 observations that do not have sufficient analysts' forecasts data. Returns are obtained from the Center for Research in Security Prices (CRSP) data file. We eliminate another 57,451 observations lacking of return data. Finally, we exclude 14,294 observations that are in the finance and utility industries. Our final sample has 22,583 firm year observations and 4,271 firms. Table 1 details the sample selection process. 
Table 1. Sample Composition

\begin{tabular}{lrr}
\hline Initial CompuStat Firms & 295,136 \\
Less: & & \\
Analysts forecasts data are not available & $-200,808$ & \\
CRSP return data are not available & $-57,451$ \\
Financial and Utility firms & $-14,294$ & \\
& & $-272,553$ \\
Final Sample - Firm -Years & & 22,583 \\
\hline
\end{tabular}

Table 2 describes our sample composition. Panel A presents the sample distribution over the years. There are more observations in 1990s than in 1980s. That is because more analysts cover more companies after 1990s. Some variation in annual observations are noted, however there is no large cluster of firms in any given year. Panel B presents the industry distribution of our sample defined using one-digit SIC codes. We note a cluster of firm-year observations in the manufacturing, machinery and electronics industry $(\mathrm{SIC}=3)$. The majority of the rest of the sample is distributed evenly in the food, tobacco, textiles, paper, and chemicals industries $(\mathrm{SIC}=2)$, wholesale and retail industries $(\mathrm{SIC}=5)$, and service industry $(\mathrm{SIC}=7)$. In the multivariate analyses, we include industry and year indicators to control for industry and year effects.

Table 2. Sample compositions

Panel A. Sample distribution over years

\begin{tabular}{|c|c|c|c|c|}
\hline YEAR & Frequency & Percent & $\begin{array}{l}\text { Cumulative } \\
\text { Frequency }\end{array}$ & $\begin{array}{r}\text { Cumulative } \\
\text { Percent }\end{array}$ \\
\hline 1985 & 76 & 0.34 & 76 & 0.34 \\
\hline 1986 & 189 & 0.84 & 265 & 1.17 \\
\hline 1987 & 229 & 1.01 & 494 & 2.19 \\
\hline 1988 & 297 & 1.32 & 791 & 3.5 \\
\hline 1989 & 422 & 1.87 & 1,213 & 5.37 \\
\hline 1990 & 420 & 1.86 & 1,633 & 7.23 \\
\hline 1991 & 492 & 2.18 & 2,125 & 9.41 \\
\hline 1992 & 535 & 2.37 & 2,660 & 11.78 \\
\hline 1993 & 657 & 2.91 & 3,317 & 14.69 \\
\hline 1994 & 681 & 3.02 & 3,998 & 17.7 \\
\hline 1995 & 714 & 3.16 & 4,712 & 20.87 \\
\hline 1996 & 791 & 3.5 & 5,503 & 24.37 \\
\hline 1997 & 897 & 3.97 & 6,400 & 28.34 \\
\hline 1998 & 908 & 4.02 & 7,308 & 32.36 \\
\hline 1999 & 843 & 3.73 & 8,151 & 36.09 \\
\hline 2000 & 743 & 3.29 & 8,894 & 39.38 \\
\hline 2001 & 813 & 3.6 & 9,707 & 42.98 \\
\hline 2002 & 895 & 3.96 & 10,602 & 46.95 \\
\hline 2003 & 1,094 & 4.84 & 11,696 & 51.79 \\
\hline 2004 & 1,233 & 5.46 & 12,929 & 57.25 \\
\hline 2005 & 1,299 & 5.75 & 14,228 & 63 \\
\hline 2006 & 1,342 & 5.94 & 15,570 & 68.95 \\
\hline 2007 & 1,372 & 6.08 & 16,942 & 75.02 \\
\hline 2008 & 1,352 & 5.99 & 18,294 & 81.01 \\
\hline 2009 & 1,267 & 5.61 & 19,561 & 86.62 \\
\hline 2010 & 1,332 & 5.9 & 20,893 & 92.52 \\
\hline 2011 & 1,325 & 5.87 & 22,218 & 98.38 \\
\hline 2012 & 365 & 1.62 & 22,583 & 100 \\
\hline
\end{tabular}


Panel B. Industry distribution

\begin{tabular}{|c|c|c|}
\hline One-digit SIC & Frequency & Percent \\
\hline 0-1 (Agriculture, mining, oil and construction) & 1,592 & $7.05 \%$ \\
\hline 2 (Food, tobacco, textiles, paper and chemicals) & 4,445 & $19.68 \%$ \\
\hline 3 (Manufacturing, machinery and electronics) & 7,945 & $35.18 \%$ \\
\hline 4 (Transportation and communications) & 381 & $1.69 \%$ \\
\hline 5 (Wholesale and retail) & 3,206 & $14.20 \%$ \\
\hline 7 (Services) & 3,833 & $16.97 \%$ \\
\hline 8-9 (Health, legal and educational services and other) & 1,181 & $5.23 \%$ \\
\hline Total & 22,583 & $100.00 \%$ \\
\hline
\end{tabular}

\section{Empirical Results}

To start our analysis, we first replicate the conditional conservatism in earnings as documented by prior studies. Table 3 presents the results which are consistent with prior findings (Basu 1997, Li 2010, Ettredge et al. 2012, etc.). Both coefficients on RET and RET*NEG are significantly positive and the differential timeliness ratio is 17.99 , which indicate that bad news is incorporated in earnings in a more timely manner than good news.

Table 3. Earnings Conservatism $(\mathrm{n}=22,583)$

\begin{tabular}{lccc}
\hline Parameter & Predicted sign & Estimate & p-value \\
\hline Intercept & $?$ & 0.1086 & 0.0115 \\
NEG & $?$ & -0.0106 & 0.0012 \\
RET & + & 0.0109 & 0.0077 \\
RET*NEG & + & $\mathbf{0 . 1 8 4 7}$ & $<.0001$ \\
& & & \\
Industry fixed effect & & Yes & \\
Year fixed effect & & Yes & \\
Differential timeliness ratio & & 17.99 & \\
Adjusted $R^{2}$ & & $19.19 \%$ & \\
\hline
\end{tabular}

This table reports results from estimating the following multivariate regression:

$$
\mathrm{EPS}_{\mathrm{it}} / \mathrm{P}_{\mathrm{it}-1}=\alpha_{0}+\alpha_{1} \mathrm{NEG}_{\mathrm{it}}+\alpha_{2} \mathrm{RET}_{\mathrm{it}}+\alpha_{3} \mathrm{RET}_{\mathrm{it}}{ }^{*} \mathrm{NET}_{\mathrm{it}}+\varepsilon_{\mathrm{it}}
$$

$E S_{i t}$ is the earnings per share for firm $i$ in fiscal year $t, P_{i t-1}$ is stock price per share at the beginning of fiscal year $t$, $\mathrm{RET}_{\text {it }}$ is the stock return on firm $\mathrm{i}$ from 9 months before fiscal year end $\mathrm{t}$ to three months after fiscal year-end $\mathrm{t}, \mathrm{NEG}_{\text {it }}$ is a dummy variable, $=1$ if $\operatorname{RET}_{\mathrm{it}}<0,=0$ otherwise. Differential timeliness ratio calculated as is $\left(\alpha_{2}+\alpha_{3}\right.$.) / $\alpha_{2}$ reflects the relative timeliness of the firm's incorporation of bad new relative to good news in earnings. $p$-values (two-sided) are obtained using standard errors clustered by firm. All variables are winsorized at the 1\% and $99 \%$ level to mitigate the influence of outliers.

\subsection{Analysts' Short-term Forecasts and Conditional Conservatism}

Table 4 summarizes the results from testing hypothesis 1 . Two points are noteworthy from the results. First, as expected, we find the analysts' short-term earnings forecasts are conservative in a similar fashion as earnings. The coefficient on RET*NEG, $\beta_{3}$, is positive and highly significant (p-value $<0.0001$ ) for all three regressions when the dependent variable is analysts' $t+1, t+2, t+3$ earnings forecasts, respectively. Second, as the forecast horizon increases, the analysts' forecasts become less conservative. The coefficients on REG*NEG for the three regressions are $0.0708,0.0447$, and 0.0142 , respectively. The estimates are decreasing as forecast horizon becomes longer, which indicates over the long run, both good news and bad news will ultimately be incorporated in earnings The differential timeliness ratio conveys the same information. For analysts' next year's earnings forecasts the ratio is 25.44. It decreases to 4.35 for analysts' forecasts for two years, and to 1.55 for analysts' forecasts for three years. 
Table 4. Analysts' short-term forecasts and conservatism $(n=22,583)$

Panel A. Dependent Variable $=$ Analysts' one year ahead forecast

\begin{tabular}{lccc}
\hline Parameter & Predicted sign & Estimate & p-value \\
\hline Intercept & $?$ & 0.0728 & $<.0001$ \\
NEG & $?$ & -0.0027 & 0.0248 \\
RET & + & 0.0029 & 0.0895 \\
RET*NEG & + & $\mathbf{0 . 0 7 0 8}$ & $<.0001$ \\
& & & \\
Industry fixed effect & & Yes \\
Year fixed effect & \multicolumn{3}{|c}{ Yes } \\
Differential timeliness ratio & & 25.44 & \\
Adjusted $\mathrm{R}^{2}$ & & $13.37 \%$ & \\
\hline
\end{tabular}

Panel B. Dependent Variable $=$ Analysts' two year ahead forecast

\begin{tabular}{lccc}
\hline Parameter & Predicted sign & Estimate & p-value \\
\hline Intercept & $?$ & 0.0796 & $<.0001$ \\
NEG & $?$ & 0.0019 & 0.0515 \\
RET & + & 0.0133 & $<.0001$ \\
RET*NEG & + & $\mathbf{0 . 0 4 4 7}$ & $<.0001$ \\
& & & \\
Industry fixed effect & \multicolumn{3}{|c}{ Yes } \\
Year fixed effect & \multicolumn{3}{|c}{ Yes } \\
Differential timeliness ratio & & 4.35 & \\
Adjusted $\mathrm{R}^{2}$ & & $21.56 \%$ & \\
\hline
\end{tabular}

Panel C. Dependent Variable $=$ Analysts' three year ahead forecast

\begin{tabular}{|c|c|c|c|}
\hline Parameter & Predicted sign & Estimate & p-value \\
\hline Intercept & $?$ & 0.0879 & $<.0001$ \\
\hline NEG & $?$ & 0.0035 & 0.0005 \\
\hline RET & + & 0.0259 & $<.0001$ \\
\hline RET*NEG & + & 0.0142 & $<.0001$ \\
\hline Industry fixed effect & & Yes & \\
\hline Year fixed effect & & Yes & \\
\hline Differential timeliness ratio & & 1.55 & \\
\hline Adjusted $\mathrm{R}^{2}$ & & $23.39 \%$ & \\
\hline
\end{tabular}

This table reports results from estimating the following multivariate regression:

$$
\mathrm{AF}_{\mathrm{it}} / \mathrm{P}_{\mathrm{it}-1}=\beta_{0}+\beta_{1} \mathrm{NEG}_{\mathrm{it}}+\beta_{2} \mathrm{RET}_{\mathrm{it}}+\beta_{3} \mathrm{RET}_{\mathrm{it}}{ }^{*} \mathrm{NET}_{\mathrm{it}}+\varepsilon_{\mathrm{it}}
$$

$\mathrm{AF}_{\mathrm{it}}$ is the consensus analysts' short-term forecast of earnings per share for firm $\mathrm{i}$ in year $\mathrm{t}$, , $\mathrm{P}_{\mathrm{it}-1}$ is stock price per share at the beginning of fiscal year $\mathrm{t}, \mathrm{RET}_{\text {it }}$ is the stock return on firm i from 9 months before fiscal year end $t$ to three months after fiscal year-end $\mathrm{t}, \mathrm{NEG}_{\mathrm{it}}$ is a dummy variable, $=1$ if $\mathrm{RET}_{\mathrm{it}}<0,=0$ otherwise. Differential 
timeliness ratio calculated as is $\left(\beta_{2}+\beta_{3}\right.$.) / $\beta_{2}$ reflects the relative timeliness of the analysts' incorporation of bad new relative to good news in short-term forecasts. $p$-values (two-sided) are obtained using standard errors clustered by firm. All variables are winsorized at the $1 \%$ and $99 \%$ level to mitigate the influence of outliers.

\subsection{Analysts' Long-term Forecasts and Conditional Conservatism}

This leads to our second hypothesis to examine analysts' long-term forecasts. Table 5 reports the results from testing hypothesis 2 . We find the analysts' long term forecasts do not display any conservatism. The $\gamma 3$ is 0.0050 (close to 0 ) and is insignificant ( $\mathrm{p}$-value $=0.2914$ ). In addition, the differential timeliness ratio equals 1.1 , which suggests the analysts incorporate both bad news and good news into their long-term forecasts at a similar timely fashion.

Table 5. Analysts' long-term forecasts and conservatism $(n=22,583)$

\begin{tabular}{cccc}
\hline Parameter & Predicted sign & Estimate & p-value \\
\hline Intercept & $?$ & 0.1109 & $<.0001$ \\
NEG & $?$ & 0.0069 & $<.0001$ \\
RET & + & 0.0439 & $<.0001$ \\
RET*NEG & $?$ & $\mathbf{0 . 0 0 5 0}$ & $\mathbf{0 . 2 9 1 4}$ \\
& & & \\
Industry fixed effect & & Yes & \\
Year fixed effect & & Yes & \\
Differential timeliness ratio & & 1.11 & \\
Adjusted $\mathrm{R}^{2}$ & & $20.19 \%$ & \\
\hline
\end{tabular}

This table reports results from estimating the following multivariate regression:

$$
\mathrm{AF}_{\mathrm{iLT}} / \mathrm{P}_{\mathrm{it}-1}=\gamma_{0}+\gamma_{1} \mathrm{NEG}_{\mathrm{it}}+\gamma_{2} \mathrm{RET}_{\mathrm{it}}+\gamma_{3} \mathrm{RET}_{\mathrm{it}} * \mathrm{NET}_{\mathrm{it}}+\varepsilon_{\mathrm{it}}
$$

$\mathrm{AF}_{\mathrm{iLT}}$ is the consensus analysts' long-term forecast of earnings per share for firm $\mathrm{i}$ in year $\mathrm{t}$. , $\mathrm{P}_{\mathrm{it}-1}$ is stock price per share at the beginning of fiscal year $\mathrm{t}, \mathrm{RET}_{\text {it }}$ is the stock return on firm $\mathrm{i}$ from 9 months before fiscal year end $\mathrm{t}$ to three months after fiscal year-end $\mathrm{t}, \mathrm{NEG}_{\mathrm{it}}$ is a dummy variable, $=1$ if $\mathrm{RET}_{\text {it }}<0,=0$ otherwise. Differential timeliness ratio calculated as is $\left(\gamma_{2}+\gamma_{3}.\right) / \gamma_{2}$ reflects the relative timeliness of the analysts' incorporation of bad new relative to good news in long-term forecasts. $p$-values (two-sided) are obtained using standard errors clustered by firm. All variables are winsorized at the $1 \%$ and $99 \%$ level to mitigate the influence of outliers.

\subsection{Robustness Check}

Following Pae and Thornton (2010) we run the robustness check with Fama and MacBeth (1973) regression method. We find that the results are qualitatively the same. In addition, we further examine whether the quality of analysts' long-term forecasts is influenced by low beginning-of-year balance sheet reserves. (Note 2)

According to previous studies, when the beginning-of-year balance sheet reserves are low, the firms exhibit a greater degree of conditional conservatism. We use beginning market-to-book as the proxy for beginning-of-year balance sheet reserves. We run the following regression

$$
\begin{aligned}
& \mathrm{AF}_{\text {it }} / \mathrm{P}_{\mathrm{it}-1}=\beta_{0}+\beta_{1} \mathrm{NEG}_{\mathrm{it}}+\beta_{2} \mathrm{RET}_{\mathrm{it}}+\beta_{3} \mathrm{RET}_{\mathrm{it}} * \mathrm{NET}_{\mathrm{it}}+\beta_{4} \mathrm{DMTB}_{\mathrm{it}-1}+\beta_{5} \mathrm{DMTB}_{\mathrm{it}-1} * \mathrm{NEG}_{\mathrm{it}}+\beta_{6} \mathrm{DMTB}_{\mathrm{it}-1} * \mathrm{RET}_{\mathrm{it}}+\beta_{7} \\
& \mathrm{DMTB}_{\mathrm{it}-1} * \mathrm{RET}_{\mathrm{it}} * \mathrm{NET}_{\mathrm{it}}+\varepsilon_{\mathrm{it}}
\end{aligned}
$$

where DMTB $\mathrm{B}_{\mathrm{it}-1}$ is an indicator variable equal to 1 when $\mathrm{MTB}_{\mathrm{it}-1}$ is less than the sample median.

Based on prior studies, we predict that for short-term analysts' forecasts, the coefficient on $\mathrm{DMTB}_{\text {it-1 }} * \mathrm{RET}_{\mathrm{it}} * \mathrm{NET}_{\text {it }}$, $\beta_{7}$, is positive; for long-term analysts' forecasts, the coefficient should be insignificant or negative. Our results are consistent with our prediction. Therefore, we conclude that the quality of the analysts' long-term forecasts is not influenced by low beginning-of-year balance sheet reserves.

\section{Conclusions}

This study investigates whether financial analysts incorporate accounting conservatism into their earnings forecasts. This question is important in that the accounting conservatism is well documented in the literature and the analysts play an important role in the capital market. Prior studies generally focus on analysts' short-term forecasts. This study extends the previous research by examining not only the analysts' short-term forecasts but also the analysts' long-term forecasts. 
We find that analysts' short-term earnings forecasts exhibit similar conditional conservatism as accounting earnings. That is, bad news is recognized in a more timely fashion than good news. When we examine the analysts' long-term earnings forecasts, the conditional conservatism disappears because in a long-run both good news and bad news will be realized and recognized. Therefore, the differential timeliness of bad news versus good news goes away in analysts' long-term earnings forecasts.

In the accounting conservatism research literature, it is important to have a good proxy for good news and bad news in order to accurately measure the conservatism. Researchers have attempted to use analysts' short-term forecasts revision as a proxy for good news and bad news. This study implies that future research can utilize analysts' long-term earnings forecasts as a complementary property of analysts' forecasts in testing whether analysts correctly incorporate information into their forecasts as forecast errors may be noisy.

\section{References}

Bartov, E., Givoly, D., \& C. Hayn. (2002). The rewards to meeting or beating earnings expectations. Journal of Accounting and Economics 33(2): 173-204. http://dx.doi.org/10.1016/S0165-4101(02)00045-9

Basu, S. (1997). The conservatism principle and the asymmetric timeliness of earnings. Journal of Accounting and Economics 24 (1):3-37. http://dx.doi.org/10.1016/S0165-4101(97)00014-1

Brown, L., Caylor, M. (2005). A temporal analysis of quarterly earnings thresholds: propensities and valuation consequences. Accounting Review 80: 423-440. http://dx.doi.org/10.2308/accr.2005.80.2.423

Dietrich, J. R., K. A. Muller, \& E. J. Riedl. (2007). Asymmetric timeliness tests of accounting conservatism. Review of Accounting Studies 12:95-124. http://dx.doi.org/10.1007/s11142-006-9023-y

Ettredge, M., Y. Huang \& W. Zhang. (2012). Earnings restatements and differential timeliness of accounting conservatism. Journal of Accounting and Economics 53(3): 489-503. http://dx.doi.org/10.1016/j.jacceco.2012.01.002

Fama, E., \& J. MacBeth. (1973). Risk, return, and equilibrium: Empirical tests, Journal of Political Economy 81: 607-636. http://dx.doi.org/10.1086/260061

Givoly, D., C. Hayn, \& A. Natarajan. (2007). Measuring reporting conservatism. The Accounting Review 82(1): 65-106. http://dx.doi.org/10.2308/accr.2007.82.1.65

Gotti, G. (2008). Conditional Conservatism in Accounting: New Measure and Tests of Determinants. Working paper. University of Massachusetts Boston

Hong, H. \& J. Kubik. (2003). Analyzing the Analysts: Career Concerns and Biased Earnings Forecasts, Journal of Finance, v. 58 (1), 313-351. http://dx.doi.org/10.1111/1540-6261.00526

Li, D. (2010). Does auditor tenure affect accounting conservatism? Further evidence. Journal of. Accounting and Public policy 29(3): 226-241. http://dx.doi.org/10.1016/j.jaccpubpol.2010.03.004

Louis, H, T. Lys, \& A. Sun. (2008). Conservatism and analyst earnings forecast bias. Working paper.

Matsumoto, D. (2002). Management's incentives to avoid negative earnings surprise. The Accounting Review 77 (3): 483-514. http://dx.doi.org/10.2308/accr.2002.77.3.483

Mikhail M., B. Walther, \& R. Willis. (1999). Conflict of Interest and the Credibility of Underwriter Analyst Recommendations, Review of Financial Studies, v. 12(4), 653-686. http://dx.doi.org/10.1093/rfs/12.4.653

Pae, J. \& D. Thornton. (2010). Association between Accounting Conservatism and Analysts' Forecast Inefficiency. Asia-Pacific Journal of Financial Studies, 39: 171-197. http://dx.doi.org/10.1111/j.2041-6156.2010.00008.x

Pope, P., \& M. Walker. (1999). International differences in timeliness, conservatism and classification of earnings. Journal of Accounting Research 37 (Supplement): 53-99. http://dx.doi.org/10.2307/2491345

Watts, R. (2003). Conservatism in Accounting Part I: Explanations and Implications. Accounting Horizons. V 17(3): 207-221. http://dx.doi.org/10.2308/acch.2003.17.3.207

\section{Notes}

Note 1. Given Patatoukas and Thomas (2011)'s findings, the results should be interpreted with caution.

Note 2 . We thank the anonymous referee for these suggestions. 